\title{
1920 Tarihli Çok Gizli İngiliz İstihbarat Notundan Türk- Rus iliş̧kilerine Dair İki Belge Ve Analizleri
}

\author{
Fatih Turgay Eldem *
}

(ORCID: 0000-0002-5263-4692)

Makale Gönderim Tarihi

16.12.2020
Makale Kabul Tarihi

29.03.2021

\section{Atıf Bilgisi/Reference Information}

Chicago: Eldem, F. T., "1920 Tarihli Çok Gizli İngiliz i̇stihbarat Notundan TürkRus Iliş̧ilerine Dair iki Belge Ve Analizleri", Vakanüvis-Uluslararası Tarih Araştırmaları Dergisi, 6/1 (2021): 118-138.

APA: Eldem, F. T. (2021). 1920 Tarihli Çok Gizli İngiliz İstihbarat Notundan TürkRus Illişkilerine Dair îki Belge Ve Analizleri. Vakanüvis-Uluslararası Tarih Araştırmaları Dergisi, 6 (1) , 118-138.

\section{Öz}

Bu makalede Birleşik Krallık (Ingiltere) Hükümeti Hindistan Ofisi'nde siyasi istihbarat subayı olan Binbaşı Norman N. E. Bray'in 18 Kasım 1920 tarihinde yazdığı çok gizli kurum notu ekleri tercüme edilmiş ve analizleri yapılmıştır. Eklerden ilki, yazılı müzakereleri Mustafa Kemal'in Vladimir Lenin'e yazdığı ünlü 26 Nisan 1920 tarihli mektubuyla başlayıp, Temmuz 1920'de kesinleşen askerisiyasi anlaşmanın metnidir. İkinci ek ise Kazım Karabekir'in Ekim 1920'de Mustafa Kemal'e gönderdiği, Bolşeviklerin Türk Milliyetçilerinden kabulünü istediği koşulları bildiren telgraftır. Belgelerin içerik analizlerinden BMM Hükümeti'nin, Bolşevik Rus Hükümeti ile Moskova Antlaşmasından çok önce anlaştığı ve Bolşeviklerin Atatürk Devrimlerinde oldukça etkili olduğu görülmüştür.

Anahtar Kelimeler: Moskova Antlaşması, Atatürk Devrimleri, Bolşevik Rusya, İngiliz İstihbaratı, Binbaşı Norman Bray

\footnotetext{
* Kıdemli Ticaret Uzmanı, T. C. Ticaret Bakanlığı, eldem_ft@outlook.com.
}

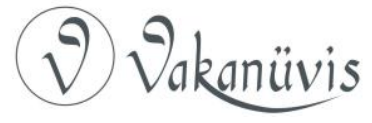




\title{
Two Documents on Turkish-Russian Relations From the Very Secret English Intelligence Note Dated 1920 and Their Analyses
}

\begin{abstract}
In this article, the very secret departmental note annexes written by Major Norman N. E. Bray, who was a political intelligence officer attached to the India Office of the United Kingdom (UK) Government, on 18 November 1920 have been translated and analyzed. The first of the annexes is the text of the military-political agreement, whose written negotiations started with the famous letter of Mustafa Kemal to Vladimir Lenin dated 26 April 1920 and concluded in July 1920. The second annex is the telegram Kazim Karabekir sent to Mustafa Kemal in October 1920, stating the conditions under which the Bolsheviks asked Turkish Nationalists to be accepted. From the content analysis of the documents, it has been seen that the GNA Government agreed with the Bolshevik Russian Government long before the Moscow Treaty and that the Bolsheviks were very influential in the Atatürk Revolutions.
\end{abstract}

Keywords: Moscow Treaty, Atatürk Revolutions, Bolshevik Russia, British Intelligence, Major Norman Bray

Milli Mücadele dönemi Türk-Rus ilişkileri Türkçe literatürde çokça işlenmiştir. Anılan literatürün çoğunda, hep aynı bilgilerin tekrarlandığı ve neredeyse hiç analiz yapılmadığı görülmektedir. Bu makalenin amacı, İngiliz gizli arşivinde yeni bulunan belgeler yardımıyla, önceki ve sonraki gelişmeler üzerinde mütevazi analizler yapmaktır. Makalede ilk olarak, BMM Hükümeti Reisi Mustafa Kemal'in Bolşevik Rus Hükümeti'ne yazdığı ünlü 26 Nisan 1920 tarihli mektubu (teklifname) ile başlayan yazılı müzakereler sonucunda Temmuz 1920'de kesinleşen askeri-siyasi anlaşmanın (mutabakatın), İngiliz istihbaratının eline geçen metni incelenecektir. Bahsi geçen metin, Katar Sayısal Kütüphanesinin çevrimiçi sayfasında (www.qdl.qa) fotoğrafları bulunan "Situation in Middle East" (Ortadoğu'da Durum) adlı çok gizli kurum notunun II-B ekidir. Not, Birleşik Kralık (İngiltere) Hükümeti Hindistan Ofisi siyasi istihbarat subayı Binbaşı Norman N. E. Bray tarafından, 18 Kasım 1920 tarihinde Londra'da yazılmıştır. İkinci olarak Ekim 1920'de Kazım Karabekir'in Mustafa Kemal'e gönderdiği, Bolşeviklerin Türk Milliyetçilerinden kabulünü istediği koşulları bildiren telgraf ele alınacaktır. Söz konusu telgraf metni de aynı notun II-A ekidir. Belgelerin içerik analizinden sonra şunlar anlaşılmıştır ki BMM Hükümeti, Bolşevik

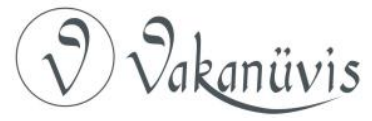


Rusya Hükümeti'yle 16 Mart 1921'de Dostluk ve Kardeşlik Antlaşmasını (Moskova Antlaşmasını) yapmadan önce onlarla gizli askeri-siyasi bir anlaşma yapmış; Mustafa Kemal ve BMM Hükümeti, Mudanya Ateşkesinden (11 Ekim 1922'den) sonra başlattıkları devrimlerini (Atatürk Devrimleri), Bolşeviklerin Türk Milliyetçilerinin tanımasını istediği aşağıdaki şartları kabul etmeleri sonucunda pacta sunt servanda ${ }^{1}$ yapmışlardır.

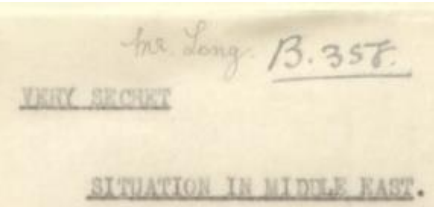

(liote by lliajor Bray, Political Intelligence.

officer, attached to India office).

16 Mart 1920'de İstanbul'daki Meclis-i Mebusan işgal kuvvetlerince basılıp, dağıtılıktan sonra Heyet-i Temsiliye üyeleri ve kolordu komutanları artık işgalden kurtulmak için Bolşeviklerle anlaşma yapmak gerektiğine ikna olmuştu. Tam bu sırada Kızılordu Beyazordu'yu yenerek, Kuzey Kafkasya'ya dayanmıştı. Erzurum'daki 15. Kolordu komutanı Kazım Karabekir, Kafkasların güneyindeki Elviye-yi Selase denilen ve Ermeni Cumhuriyetinin işgalindeki Kars-Ardahan ve Batum'u kurtarmak için yapılacak askeri harekatta, Kızılordu'yla karşı karşıya geldiğinde vuku bulacak anlaşmazlıklardan kaçınmak için Bakü’ye acilen bir askeri heyet gönderilmesi gerektiğini düşündü. Bu nedenle heyet gönderilmesi önerisini ve onlara verilecek talimatları içeren metni, onaylanmak üzere Ankara'daki Heyet-i Temsiliye Başkanı Mustafa Kemal'e 18 Nisan 1920 tarihinde gönderdi. (Kâzım Karabekir, istiklâl Harbimiz, Cilt. 2, Yapı Kredi Yayınları, İstanbul, 2008, s. 708) Defalarca tekitten sonra cevap 26 Nisan'da geldi. Mustafa Kemal talimatı sadece

1 Özel ve kamu hukukunda geçen "ahde vefa gösterme", (ahdin ihlali halinde ahitte müeyyide mevcut değilse) tabii ki özel kişilerin ve kamu tüzel kişilerin temsilcilerinin vicdanına kalmıştır.

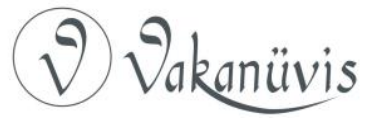


tadil ederek, onaylamıştı. Fakat Kazım Karabekir, bir oldu-bittiyle talimatı bir anlaşma teklifine dönüştürdü ve 28 Nisan'da talimatı (teklifnameyi), bir subayla Moskova'ya gönderdiğini Mustafa Kemal'e bildirdi. $^{2}$

Büyük Millet Meclisi'nin Moskova Sovyet Hükümeti'ne birinci teklifnamesi (mektup), 26/4/1920:

"1 - Emperyalist hükümetler aleyhine harekâtı ve bunların tahtı tahakküm ve esaretinde bulunan mazlum insanların tahlisi gayesini istihdaf eden Bolşevik Ruslarla tevhidi mesai ve harekâtı kabul ediyoruz. 2 - Bolşevik kuvvetleri Gürcistan üzerine harekâtı askeriye yapar veyahud takip edeceği siyaset ve göstereceği tesir ve nüfuzla Gürcistan'ın da Bolşevik ittifakına dahil olmasını ve içlerindeki İngiliz kuvvetlerini çıkarmak üzere bunlar aleyhine harekâta başlamasını temin ederse, Türkiye Hükümeti de emperyalist Ermeni Hükümeti üzerine harekât-ı askeriye icrasını ve Azerbaycan Hükümeti'ni de Bolşevik zümre-i düveliyisine idhal etmeyi taahhüt eyler. 3 - Evvelâ millî topraklarımızı tahtı işgâlinde bulunduran emperyalist kuvvetleri tard ve atiyen emperyalizm aleyhine vuku bulacak mücadelât-ı müşterekemiz için kuva-yı dahiliyemizi taazzuv ettirmek üzere, şimdiden ilk taksit olarak beş milyon altının ve takarrür ettirilecek miktarda cephane vesair vesait-i fenniye-i harbiye ve malzeme-i sıhhiyenin ve yalnı şarkta icra-yı harekât edecek kuvvetler için erzakın Rus Sovyet Cumhuriyetince temini lazımdır. (...) Ihtiramat-ı faike ve hissiyat-ı samimiyetimizin kabulünü rica eyleriz.

Büyük Millet Meclisi Reisi M. Kemal” (Karabekir, 2008, ss. 747-748)

Moskova Sovyet Hükümeti'nin Büyük Millet Meclisi'ne mukabil teklifnamesi (mektup), 2/6/1920:

"Sovyet Hükümeti, her iki milleti tehdit eden ecnebi emperyalizmine karşı mücadeleye iştirak eylediğini bildiren ve Rus Sovyet Hükümeti'yle münasebat-ı muntazamaya girişmek arzusunu izhar eden mektubunuzu aldığını bildirmekle kesb-i şeref eyler. Başında Ankara Büyük Millet Meclisi bulunan yeni Türk Hükümeti'nin harici siyasetinin esasatına, Rus Sovyet Hükümeti memnuniyetle muttali oldu. Bu prensipler ber vech-i atidir: 1-Türkiye'nin istiklalinin ilanı, 2-Gayrı kabili itiraz Türk arazisinin Türk devletine ilhakı, 3-Arabistan ve Suriye'nin müstakil devletler gibi

\footnotetext{
2 Kazım Karabekir'in teklifnameyi Halk Komiserleri Konseyi Başkanı Vladimir í. Lenin'e hitaben yazdığı anlaşıııyor. (Jaeschke, 2011, s. 161)
}

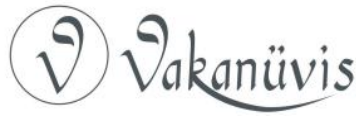


ilanı, 4-Büyük Millet Meclisi tarafından (alınan) karara nazaran Türkiye Ermenistan'ında, Kürdistan'da, Lazistan'da Batum arazisinde, Şarki Trakya'da, Türk ve Arapların müştereken bulundukları bütün arazideki milletlerin kendi mukadderatlarının tesbit ve tayinini kendilerine bırakmak. Sovyet Hükümeti mültecilerin ve arzuları hilafında hicret etmiş muhacirlerin de bu menatıkta serbestçe referanduma iştirak edebilmeleri için bunların mahallerine avdet ettirilmelerini tabii buluyor. 5-Başında Büyük Millet Meclisi bulunarak teşekkül eden yeni Türk Hükümeti'ne ait arazide ve ekalliyette kalan milletler için Avrupa'nın en serbest hükümetlerinde bulunan milli ekalliyetler için tanınmış olan bütün hukukun tanınması, 6-Boğazlar meselesinin, Karadeniz sahil hükümetleri tarafından akdedilecek bir konferansa tevdii, 7-Kapitülasyonların ve ecnebi devletlerin mali kontrolünün ilgası, 8- Her nevi ecnebi nüfuz mıntıkalarının ilgası

Rus Sovyet Hükümeti, tazyik altında bulunan milletleri kurtarmak gaye -i temennisiyle emperyalizm hükümetlerine karşı tevcih edilmiş mesai ve harekât-ı askeriyeye, mutlak Büyük Millet Meclisi'nin arzusunu ahzeder. Kendi mukadderatlarını kararlaştıracak milletlerin hakkın, adaletin talep ettiği veçhile bir taraftan Türkiye, diğer taraftan Ermenistan ve Acemistan aralarında, kat'i hududun tesbiti için vuku bulacak müzekerat-ı siyasiyeye Büyük Millet Meclisi'nin müsaade edeceğini, Rus Sovyet Hükümeti ümid eder. Ve Rus Sovyet Hükümeti, her zaman alakadarânın daveti üzerine tavassutu deruhdeye müheyyadır. Türkiye ve Rusya arasında münasebat-ı dostane ve devamlı bir muhadenetin tesisi için doğrudan doğruya münasebat-ı siyasiye ve konsolosluklara ait münasebata başlanmasını Rus Sovyet Hükümeti teklif eder. (...)

\section{Büyük Millet Meclis-i Reisi Efendi!}

Bâlâdaki mevadd piş-i nazar-ı ıttılaınıza vazederken, müttehit köylü amele cumhuriyeti ahalisi namına istiklal için mücadele eden Türk halkına muvafakiyatı temenniyatımızı da iblağla kesb-i şeref eylerim.

Umur-u Hariciye Ahali Komiseri Çiçerin" (Karabekir, 2008, ss. 875876)

Mustafa Kemal 3 Temmuz'da BMM'de yapılan gizli oturumda, Dışişleri Halk Komiseri Georgi Çiçerin'in 2 Haziran tarihli mukabil teklifnamesi için şunları söylemiştir:

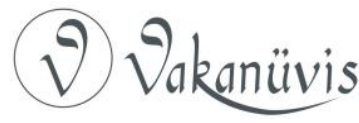


"Yalnız pakt nasyonalde ufak bir fark mevcuttur. O mevcut olan fark da hududu millimizin dahilindeki muhtelif ırklara mensup ahali-i islâmiyenin de reyine müracaat edilmesi meselesidir.

Biz haddi zatında gerek Suriye ve gerek Iraktaki insanların müstakil olmaları esasını kabul etmişizdir. Buna dair bir itirazımız yoktur. Sonra bizim kabul etmiş olduğumuz prensipler, nazarı tetkikten geçirilecek olursa, Rus Sovyet Cumhuriyeti, bazı şeyleri tabiî buluyor. Meselâ Ermenistan'daki insanların kendi mukadderatını kendi reyleriyle tayin ve tespit etmeleri; Erivan Cumhuriyetini tesis ve teşkil eden Ermenilerin müstakil olmalarını ve bu bapta arzuları her ne ise zaten kabul etmişizdir. Fakat Kürdistan, Lâzistan vesaire hakkında değil. (...)

Binaenaleyh hiç şüphe etmeyiniz ki Kürt, Lâz vesaire, reyi sorulduğu zaman bu reyi vereceklerdir. (...) Ekalliyetler hakkında da bütün dünyayı medeniyetin kabul ettiği kavanini siz de kabul ediniz diyorlar. Bu bizim için ehven bir şeydir ve biz bunu kemal-i memnuniyetle kabul etmişizdir.

(...)

Yalnız bunu arz edeyim ki burada meselâ silâhtan vesaireden bahsolunmamıştır. Bu bizim de nazarı dikkatimizi celb eylemiştir, anlamak istedik. Fakat bu bir mektuptur fazla bir şey yazmak istememişlerdir. Müsaade buyurursanız buna cevaben bizim yazdığımız mektubu da okuyayım da bir iki fıkra daha söyleyeyim: Cevabımızı Fransızcaya tercüme ettik, Fransızca yazdık; teehhür etmesin diye ve bundan evvel yine bu mealde Hariciye Vekâletinden bir mektup gönderilmiştir." (TBMM Gizli Celse Zabıtları, Cilt. 1, 3/7/1920, s. 73)

Öte yandan Büyük Millet Meclisi'nin Moskova Sovyet Hükümeti'ne 20/6/1920 tarihli ikinci teklifnamesinin metni bugüne kadar yayımlanmamıştır. Mustafa Kemal, BMM'de yukarıda verilen konuşmasında cevabi mektubu okuyayım demiş, fakat okumamıştır. Yine de konuşmasındaki Çiçerin'in mukabil teklifine ilişkin fikirlerinden başka, diğer kaynaklardan da ikinci teklifnamenin muhteviyatına ilişkin bazı bilgiler mevcuttur. Teklifnamede, "Ermenistan ve Acemistan hudutlarımızı tayin için Rus Sovyet Cumhuriyetinin tavassutunun memnuniyetle kabul ve sorunların siyasi müzakerelerle çözülmesinin tercih edildiği" de bildirilerek, "komşularımızla gayri kabil-i itiraz bir surette Türk olan bir araziyi tahrip ve ahaliyi katliâm ettiklerinden ve Garp emperyalistlerine has olan usullerde sun'i kitleler ve ekseriyetler vücuda getirmekte olduklarından şiddetle muzdarip ve müştekiyiz" denilmiş ve Ermeni tecavüzlerinin durdurulması için tavassutta bulunmaları istenmiştir. (Sadık Erdaş, "Türk-Sovyet Iliş̧ilerinin Illk Yılı ve

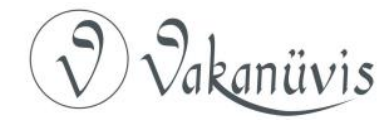


iki Kararname", Cumhuriyet Tarihi Araştırmaları Dergisi, Yıl. 13, Sayı. 26 (2017), s. 75)

İngiliz istihbaratına göre Mustafa Kemal ile Bolşevikler arasında yapılan anlaşma aşağıdadır: (Major Bray, Situation in Middle East, 1920b, India Office, pp. 12-14)

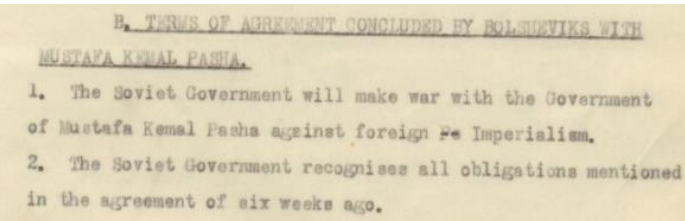

K. B. The ternas of the above agreenent are corroborated

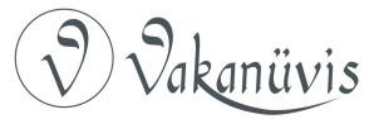




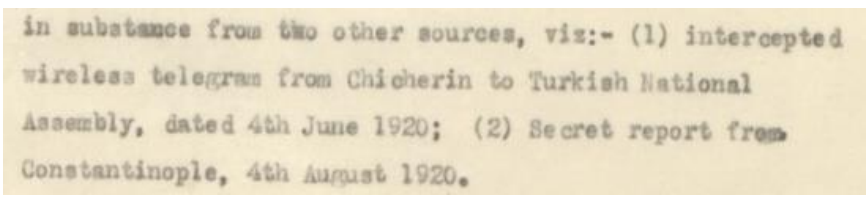

\section{Tercüme:}

\section{B. Mustafa Kemal Pașa ile Bolssevikler Tarafından Yapılan Anlaşmanın Hükümleri}

1- Sovyet Hükümeti, Mustafa Kemal Paşa Hükümeti ile beraber yabancı emperyalizmine karşı savaş yapacaktır. (Birinci teklifname, no: 1)

2- Sovyet Hükümeti altı hafta önceki anlaşmada bahsedilen tüm yükümlülükleri tanır. (Birinci teklifname, no: 2,3) (ikinci teklifname)

3- Tula'daki ${ }^{3}$ cephane fabrikası Mustafa Kemal'in kullanımına verilecektir. (Birinci teklifname, no: 3) (ikinci teklifname)

4- Sovyet Hükümeti Türkiye'nin bağımsızlığını ve tüm gerçek Türklerin kendi topraklarında yeniden birleşmelerini tanır. (Birinci teklifname, no: 2) (Mukabil teklifname, no: 1,2)

5- Sovyet Hükümeti Arabistan ${ }^{4}$ ve Suriye'nin bağımsızığını tanır. (Mukabil teklifname, no: 3)

6- Sovyet Hükümeti Kürdistan, Luristan ${ }^{5}$ ve Batum kazasını Türk Ermenilerine verir. (ikinci mukabil teklifname?)

7- Sovyet Hükümeti Doğu Trakya ve ona bağlı toprakların, kime ait olacağına karar vermelerine izin verecektir. (Mukabil teklifname, no: 4)

8- Boğazlar sorununun kesin çözümü bir Karadeniz Devletleri konferansındadır. (Mukabil teklifname, no: 6)

9- Bütün ekonomik anlaşmalar ve büyük devletler tarafından Türkiye ile yapılan nüfuz bölgeleri anlaşmaları iptal edilecektir. (Mukabil teklifname, no: 7,8)

10- Sovyet Hükümeti Ermeni -Acem -Türk sınır sorununda arabuluculuk hizmeti verecektir. (Mukabil teklifname, 2. paragraf) (ikinci teklifname)

\footnotetext{
${ }^{3}$ Tula Moskova'nın 185 km güneyinde cephane fabrikalarıyla ünlü bir şehirdir.

${ }^{4}$ Arabistan'dan kasıt Irak'tır.

5 Luristan Acemistan'ın bir vilayeti olup, yanlış yazım sonucu Doğu Karadeniz'deki Lazistan bölgesi de kastedilmiş olabilir.
}

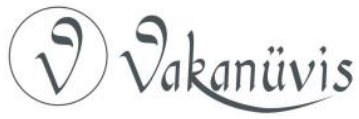


11- Mustafa Kemal Paşa Hükümeti, Bolşeviklerin Acemistan'dan taktiksel, siyasal ve diğer sebeplerden dolayı çekilmesi durumunda, Türk ve Acem askerlerin onların yerine geçmelerini kabul eder. (ikinci mukabil teklifname?)

12- Sovyet Hükümeti, Mustafa Kemal Paşa Hükümeti'ne Maveraülkafkas'da ihtiyaç duydukları tüm askeri malzemeleri toplamasına izin verir. (Birinci teklifname, no: 3) (ikinci teklifname)

Sovyet Hükümeti, biri Rus ve biri Türk olmak üzere iki askeri misyonun, planlarını sürdürmenin en iyi yöntemlerini tartışmak için Kafkasya'ya gönderilmelerini teklif eder.

(Kaynak: Çiçerin'den Mustafa Kemal'e Nota'nın kopyası; Kopenhag'da Litvinoff'a verildi.)

Dikkat: Yukarıdaki anlaşmanın şartları diğer iki kaynaktan öz olarak teyit edilmiştir. Bu kaynaklar şunlardır: 1- Çiçerin'den Türk Millet Meclisi'ne 4 Haziran 1920 tarihli telsiz telgraf dinlemesi, 2- İstanbul'dan gizli rapor, 4 Ağustos 1920

4 Temmuz'da Çiçerin'e, Türkiye Büyük Millet Meclisi'nin ikinci teklifnamesinin teslimi yapılmıştır. (Gotthard Jaeschke, Türk Kurtuluş Savaşı Kronolojisi, Mondros'tan Mudanya'ya Kadar, TTK Basımevi, Ankara, 1989, s. 111) Moskova Sovyet Hükümeti'nin, Büyük Millet Meclisi'ne ikinci mukabil teklifname sunduğuna veya Büyük Millet Meclisi'nin ikinci teklifnamesini kabul ettiğine dair bir belge bulunmamaktadır. Fakat Mustafa Kemal, 8 Temmuz'da BMM'de açık oturumda "Pekâlâ cereyan eden muhabere muhteviyatını biliyorsunuz. Sovyet Cumhuriyeti bizim muhtaç olabileceğimiz maddi muavenetin hepsini vadetmiştir. Silah, top, para vadetmiştir. (Bravo sesleri, alkışlar)" (TBMM, Zabıt Ceridesi, Cilt. 2, 8/7/1920, s. 227) diye açıklama yapıvermiştir. Bunun, 2 Haziran'dan altı hafta önceki anlaşmanın (26 Nisan teklifnamesinin), 8 Temmuz'a kadar Moskova ile yapılan müzakerelerle yukarıdaki anlaşmanın 2. Maddesinde yer bulması sonucunda olduğu anlaşılıyor. Sonuç olarak Nisan ayında askeri bir anlaşma yapma niyetiyle müzakerelere başlanmış, zaman içinde askerisiyasi bir niteliğe dönüşmüş ve Temmuz ayı itibariyle anlaşma, artık nihai

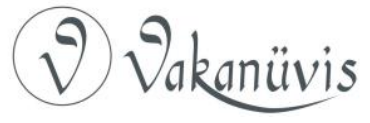


halini almış bulunmaktadır. Sonyel bu metnin 24 Ağustos'ta Türk ve Rus temsilcilerce Moskova'da parafe edilen antlaşma olduğunu iddia etmektedir. (Salâhi R. Sonyel, Kurtuluş Savaşı Günlerinde Ingiliz İstihbarat Servisi'nin Türkiye'deki Eylemleri, 2. Baskı, TTK Basımevi, Ankara, 2013, s. 96) Ancak metnin teyit edilen en son tarihi olan 4 Ağustos'ta Moskova'daki temsilciler arasında bir antlaşma yapma fikri dahi yoktu. ${ }^{6}$

Tarafların teklifnamelerindeki hükümlerin anlaşmadaki karşılıkları, tercümede parantez içinde gösterilmiştir. Anlaşmanın 6. ve 11. Maddeleri, muhtemelen Bolşeviklerin ikinci mukabil tekliflerinde yer almıştır. Sovyet Hükümeti'nin, Büyük Millet Meclisi'nin itirazı nedeniyle Türkiye Ermenistanı, Kürdistan ve Lazistan'da Batum arazisinde referandum yapılması isteğinden vazgeçtiği görülüyor. Bunun yerine anlaşmanın 6. Maddesinde Sovyet Hükümeti'nin doğrudan, (hangi Kürdistan olduğundan bahsetmeden) Kürdistan ve Luristan ile Batum kazasını Türk Ermenilerine vereceği yazılıdır. Bu sırada Acemistan'ın Gilan Vilayetini Mayıs 1920'den beri işgal etmekte olan Bolşevikler, burada Reşt Sovyet Hükümeti'ni kurmuşlar ve tüm Acemistan'ı Bolşevikleştirmek niyetindedirler. Ama anlaşmanın 11. Maddesine göre Bolşevikler Acemistan'dan çekilmek zorunda kalırlarsa, Türk ve Acem askerler onların yerine geçecektir. Kazım Karabekir'in Bolşeviklerle anlaşma yapılmasındaki asıl amacı ise anlaşmanın en son paragrafında, Bolşeviklerin ağzından örtülü şekilde tekrarlanmıştır: Türk ve Rus askeri misyonlar planlarını sürdürmenin en iyi yöntemlerini tartışmak (vuku bulacak anlaşmazlıklardan kaçınmak) için bir araya gelmelidir.

Bolşevik yöneticiler Halil Paşa'dan anlaşmanın (askeri yardım hususlarının) gizli kalmasını istemişlerdi. (Karabekir, 2008, s. 892) Ancak Mustafa Kemal 4 Ağustos tarihli kolordulara duyurusunda ordunun acilen ihtiyaç duyduğu yardımların, yapılan anlaşmaya göre Sovyet Hükümetinden temin edileceğinin müjdesini vermiştir. Ayrıca Kızılordu Başkomutanının bir tümen süvari ile bir tümen piyadeyi 15 Ağustos'a kadar geçici olarak Doğubeyazıt'a göndereceğini ifade etmiştir. (Major Norman E. E. Bray, Mesopotamia: Causes of Unrest, Report No. II,

${ }^{6}$ Antlaşma yapılması fikrini önce Türk Heyeti Başkanı Bekir Sami Bey Çiçerin'e 13 Ağustos'ta teklif etmiş, Çiçerin de kabul edince, görüşmeler 17 Ağustos'ta başlamıştı. (Sonyel, 2003, ss. 13-14)

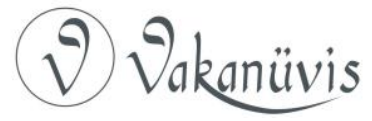


1920a, India Office, p. 11) Ama anlaşmada askeri birlik gönderilmesi hususu geçmemektedir. Mustafa Kemal 3 Temmuz'da BMM'deki konuşmasında, yeni Türk Hükümeti'nde ekalliyetlerin Avrupa hukukuna göre korunması hususunu memnuniyetle kabul ettiklerini söylediği halde, bu hüküm de anlaşmada yer almamıştır. ${ }^{7}$ Buna rağmen, not ekinin sonunda dikkat çekildiği gibi anlaşmanın şartları öz olarak geçerliliğini korumaktadır.

Mustafa Kemal, İngiliz istihbaratına göre 5 Ağustos'ta da şöyle bir ilan yayımlamıştır: (Bray, 1920a, p. 12)

“Hem bize ... hem de hiçbir zaman yenilmemiş olan Almanya'ya yardım eli uzatan kutsal Bolşevizm gücü, her zaman bize yardım edecektir.

“Mademki ittifak ettiğimiz iki büyük millet bizi destekliyor ve yardım ediyor ..., şunu tekrarlıyorum ki Kutsal İttifaka boyun eğmek ve ona hizmet etmek zorundasınız.

“(imza), Mustafa Kemal

"Türk Cumhuriyeti Cumhurbaşkanı

"5 Ağustos 1920"

Böyle bir ilanın nerede ve nasıl yayımlandığı konusunda İngiliz istihbaratı bilgi vermemektedir. Fakat o tarihte Mustafa Kemal, cephe ziyareti sırasında bölgesel Müdafaa-i Hukuk Heyetleri ile Pozantı'da bir kongre yapmıştı. Kongre ertesinde halka verdiği nutkunda, "Rusya'daki ... muazzam kuvvetin" azami yardımda bulunmayı vaat ettiğini ifade etmiştir. Fakat Aydemir'in dediği gibi, bu nutkun resmi bir metni yoktur ve mevcut kısmi metin de kongre/toplantı katılımcı şahıslarından elde edilmiştir. (Şevket S. Aydemir, Tek Adam, Cilt: 2, Remzi Kitabevi, 1999, s. 176) Öte yandan diğer kongreler sonunda bildiriler yayımlanmışken, Pozantı Kongresi sonunda bir bildirinin yayımlanmaması veya elde edilememesi Aydemir'i, Pozantı Kongresi için "veya Pozantı toplantısı" demeye sevk etmiş olmalıdır. (a.g.e., s. 175) Yukarıdaki ilandan, kongre bildirisinin İngiliz istihbaratının eline geçtiği ve Fransız Hükümeti’yle bile

\footnotetext{
7 Bu hüküm 2 Aralık 1920'de Ermeni Cumhuriyeti ile yapılan Gümrü Antlaşmasının 6. Maddesinde yer alacaktı. (Soysal, 1983, s. 25-26)
}

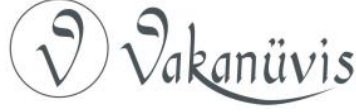


paylaşıldığı anlaşılmaktadır. Öyle ki Fransız Dışişleri Bakanı Leygues, Aralık 1920'de ilanı küçümseyerek ve Almanları yok sayarak, "Kutsal Olmayan Kemalist-Bolşevik İttifakını, Müttefikler insaflı bir sulh ile önlemelidirler" şeklinde bir beyanda bulunmuştur. (Jaeschke, 1989, s. 131) Ne Mustafa Kemal'in nutkunun ne de Kongre bildirisinin resmen hiç yayımlanmaması, ilanın doğru olduğu ve resmi tarih tarafından üstünün örtüldüğü düşüncesini doğurmaktadır.

Öte yandan ilan/bildiri kısmen veya tamamen sahte de olabilir. Çünkü Mustafa Kemal'in ilanı/bildiriyi, bu tarihte "Türk Cumhuriyeti Cumhurbaşkanı" diye alenen imzalaması, mantığa aykırıdır. BMM'nin birkaç ay önce açıldığı, hilafeti ve saltanatı esaretten kurtarmayı amaçladığını duyurduğu ve iç isyanların hâlâ devam ettiği bir dönemde, BMM Reisi Mustafa Kemal'in kendini Cumhurbaşkanı ilan etmesi mümkün değildir. Bu nedenle ilan/bildiri metni doğru olsa bile imzalayanın sıfatı sahte olmalıdır. Pozantı Kongre (varsa) bildirisinin ve Mustafa Kemal'in nutkunun tam metinlerinin yayımlanması şüpheleri giderecektir.

Bu noktada anlaşma içeriği ilgili sonraki gelişmelerden bahsetmek gerekirse, Rus piyade ve süvari tümenlerinin çağırılması gündeme gelmiş olsa da Milli Mücadele boyunca hiçbir zaman Türkiye'ye gelmemişlerdir. Sadece Kafkaslardan, savaş sırasında Ruslara esir düşmüş eski Osmanlı askerleri ve BMM Hükümeti'nin yerli halktan topladığı gönüllüler Türkiye'ye gelmiştir. (Gotthard Jaeschke, Çev. Hüseyin Zamantılı, "1919-1939 Yılları Arasındaki Türk-Rus Yakınlaşması Hakkında Bir İnceleme" (Atatürk Dönemi Sovyet Politikası Hakkında), istanbul Journal of Sociological Studies, C. 0, S. 19 (2011), s. 173) (Sonyel, 2013, s. 192) Acemistan'daki Reşt Sovyet Hükümeti 1921 sonuna doğru Bolşevik Rusya'nın da onayıyla yıkılmış, fakat Türk askerleri hiçbir zaman Bolşevik askerlerin yerine geçmemiştir. Sovyet Hükümeti, BMM ve yeni Acem Hükümet'lerinin askeri harekatlarıyla Kürdistan, Luristan ve Batum kazasını Türk Ermenilerine bırakamamıştır. Bu anlaşma, siyasi antlaşmanın sonra yapılacağı gerekçesiyle sadece askeri konuda anlaşmak üzere başlayan müzakerelerden doğduğuna göre, büyük bir intimalle sekiz ay sonra yapılacak olan Moskova Antlaşmasının gizli eki veya maddeleri yapılmıştır. Nitekim İstanbul'daki İngiliz Yüksek Komiserliği, Moskova Antlaşmasının birçok gizli askeri maddeleri

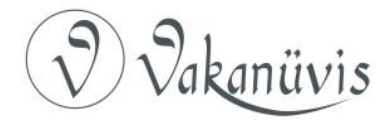


olduğuna inanmaktadır. (Salâhi R. Sonyel, Türk Kurtuluş Savaşı ve Dış Politika II, 3. Baskı, TTK Basımevi, Ankara, 2003, s. 57) Moskova Antlaşması ve eki gizli askeri anlaşma, Türk-Rus ilişkilerinin keskin iniş ve çıkışlarına paralel olarak uygulama şansı bulmuştur. 1922 yılının Haziran ayında Ankara'da Sovyet elçisi Aralof ile Hariciye Vekili Yusuf Kemal arasında günün koşullarına göre ikinci bir askeri gizli anlaşma yapılmış, fakat o da önceki anlaşmayla aynı kaderi paylaşmıştır. (Sonyel, 2013, ss. 263-264, 273-274)

İngiliz istihbaratının elde ettiği aşağıdaki belge de Bolşeviklerin, Türk Milliyetçilerinden taleplerini göstermektedir. (Bray, 1920b, p. 12) 


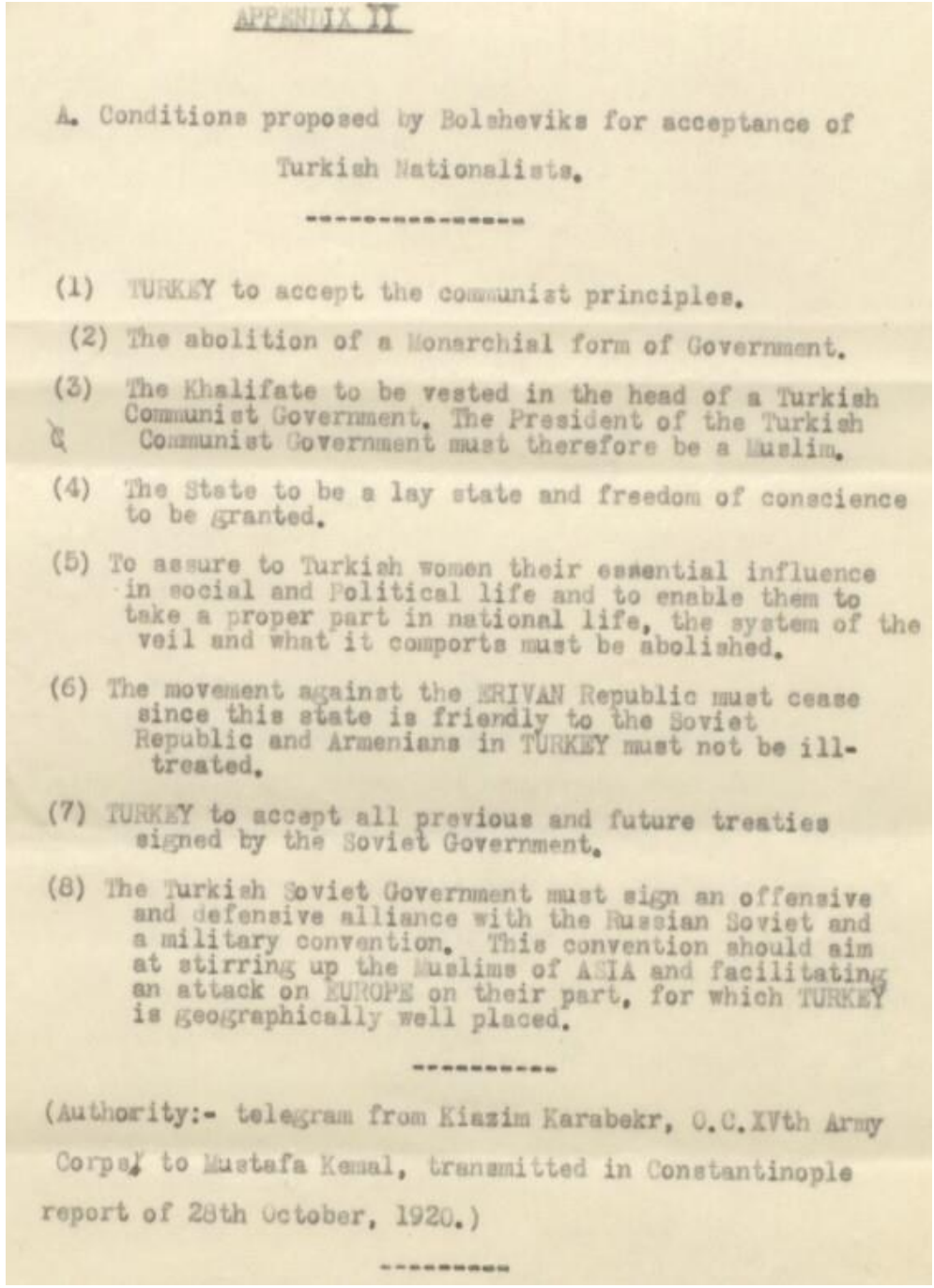

\section{Tercüme:}

\section{EK II}

A. Türk Milliyetçilerin kabul etmesi için Bolşevikler tarafından önerilen koşullar

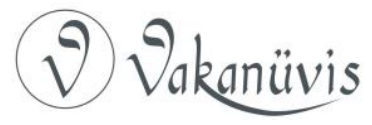


(1) Türkiye komünist ilkeleri kabul edecek.

(2) Padişahlık hükümet şekli iptal edilecek.

(3) Halifelik, komünist bir Türk Hükümeti'nin başındakine devredilecek. Bu nedenle Komünist Türk Hükümeti Başkanı bir Müslüman olmalıdır.

(4) Devlet, laik bir devlet olacak ve vicdan hürriyeti sağlanacak.

(5) Türk kadınlarının sosyal ve siyasi hayatta esas etkisini güvence altına almak ve onların milli hayatta uygun bir pay almalarını sağlamak için peçe sistemi ve bu sistemin yaptığı iptal edilmelidir.

(6) Erivan Cumhuriyeti'ne karşı yapılan intikal durdurulmalıdır. Çünkü bu devlet, Sovyet Cumhuriyeti'ne dosttur ve Türkiye'deki Ermenilere kötü davranılmamalıdır.

(7) Türkiye, Sovyet Hükümeti'nin imzaladığı önceki ve gelecekte imzalayacağı tüm antlaşmaları kabul edecek.

(8) Türk Sovyet Hükümeti, Rus Sovyet'iyle bir hücum ve savunma ittifakı ile askeri bir sözleşme imzalamalıdır. Bu sözleşmenin, Asya'daki Müslümanları kışkırtmayı ve onların Avrupa'ya saldırısını kolaylaştırmayı hedeflemesi gerekmektedir. Türkiye söz konusu saldırı için coğrafi olarak iyi bir yerdedir.

(Kaynak: 15. Kolordu Sorumlu Subayı Kazım Karabekir'den Mustafa Kemal'e telgraf, 28 Ekim 1920 tarihli İstanbul raporunda aktarıldı.)

Mustafa Kemal, 19 Mayıs 1919'da Samsun'a çıktığı zaman diğer birçok Osmanlı eliti gibi, "Bolşevizmin suret-i telakki ve tecellisi dahi müzakere edilerek esasen Kazan, Orenburg, Kırım vesaire gibi ahali-i İslamiye bunu kabul ederek, diyanet an'ane gibi işlerle zaten alakadar olmadığından, bunun memleket için bir mahzuru olamayacağı"nı düşünüyordu. (Karabekir, 2008, s. 61) Ama 22 Eylül 1919'da Amerikalı Tümgeneral James G. Harbord'a "Bolşeviklik meselesine gelince ne olursa olsun bu doktrinin ülkemizde yeri yoktur. Dinimiz, âdetlerimiz ve sosyal müesseselerimizin böyle bir doktrinle bağdaşması imkânsızdır." demişti. (Jaeschke, 2011, ss. 164-165) Talat Paşa'ya yazdığı 20 Şubat 1920 tarihli mektubunda ise "Binaenaleyh vatanımızı parçalatmak ve

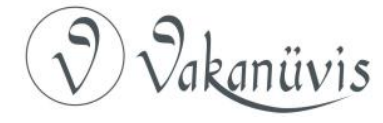


milletimizi İngiliz boyunduruğu altında görmek ihtimali meş'umu karşısında Bolşevik prensiplerini fiilen tatbik etmekte çare-i halas tahmin olunursa ... o hususa da tevessül etmek lazım gelebilir." diye yazmıştır. (ilhan Tekeli ve Selim Illkin, "Kurtuluş Savaşında Talat Paşa ile Mustafa Kemal'in Mektuplaşmaları", Belleten, TTK Basımevi, C. 44, S. 174 (1980), ss. 324-325) Dönüm noktası 16 Mart 1920'de İstanbul'un işgaliydi. Heyet-i Temsiliye üyeleri ve kolordu komutanları işgalden kurtulmak için Bolşevik prensiplerini de fiilen tatbik etmeye tevessül ettiler. Mustafa Kemal 11 Mayıs'da, Lenin'in Rusya ve Şark Müslümanlarına Tamiminin BMM'de okunmasına izin verdi. Aynı ay kurulan Yeşil Ordu Cemiyeti'nin faaliyetlerine başlangıçta göz yumdu. (Coşkun Topal, "Türk-Rus iliş̧kileri ve Moskova Anlaşması", Karadeniz Araştırmaları Enstitüsü Dergisi, 4/6 (2018), s. 318) Hatta Pozantı Kongresi sırasında Rus Sovyetleri (Şuraları) andırırcasına, yeni Adana Vilayeti Valisini ve idare heyetini halk seçti. (Erdem Çanak, "Atatürk'ün Adana Ziyaretleri", Atatürk Araştırma Merkezi Dergisi, C. 30 S. 90 (2014), ss: 55-56)

Binbaşı Bray kurum notunda, (Kasım 1920 itibariyle) Anadolu Hükümeti'nin Bolşeviklere karşı tutumunun, İttihatçıların savaş sırasında Almanya'ya karşı benimsediği tutumuyla çok benzer olduğunu ve bunun, İslamiyet'in amaçları elde edilir edilmez müttefikiyle ilişkiyi kesmeyi hatırda tutarak, ona (müttefikine) karşı hoşgörü tutumu olduğunu ileri sürmektedir. (Bray, 1920b, p. 6) Oysa bu öngörüden iki ay önce Eylül başlarında, BMM komünist Nazım Resmor'u Dahiliye Vekili olarak seçince, Mustafa Kemal Anadolu'da Bolşevik söylem ve eylemlerinin çok güçlendiğine kani olarak, hoşgörü tutumunu kısmış ve onları bastırmaya karar vermişti. 4 Eylül'de yeni Vekili tanımadığını ilan etti. Çerkez Ethem'in araya girmesiyle Resmor, iki gün sona istifa etti. (Semih E. Yalçın, "Dahiliye Vekili Nazım Bey'in İstifası Meselesi", Atatürk Araştırma Merkezi Dergisi C. XI, S. 32 (1995), ss. 408-411) Dahiliye Vekaleti (Danışıkı) Türkiye Komünist Fırkası'na 18 Ekim'de ruhsat verdi ve Yeşil Ordu Cemiyeti'nin bu fırkaya katıldığını duyurdu. (Topal, a.g.m.) Durumdan rahatsız olan Bolşevik Hükümeti, aynı tarihte Ermenilere karşı harekatın Brest-Litovsk Antlaşması sınırlarına dayanması üzerine yukarıdaki telgrafı gönderdi. Bunun üzerine Mustafa Kemal, 31 Ekim'de "komünizmin en büyük kumandanlarda kalmasını" Kazım Karabekir'e bildirdi. (Jaeschke, 1989, s. 126) Kasım ayı boyunca sessiz kalan

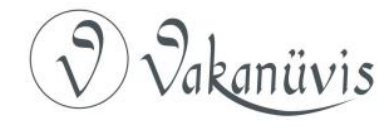


Bolşevikler Aralık başında, Dahiliye Nazırı Ahmet İzzet Paşa Mustafa Kemal ile görüşmek üzere İstanbul Hükümeti adına Bilecik'e gelmeden önce böyle bir görüşme yapılacağından haberdar olmuşlardı. 5 Aralık'ta yapılan görüşmeden önce BMM Hükümeti'ne karşı tavırlarını değiştirmiş, BMM Hükümeti'nden görüşme hakkında bilgi istemiş, yardımları durdurmuşlardı. ${ }^{8}$ (TBBM Gizli Celse Zabıtları, Cilt. 1, 25/9/1920, ss. 137-138) Bunun üzerine Hariciye Vekili Ahmet Muhtar Bey, Çiçerin'e gönderdiği notayla İstanbul Hükümeti'yle görüşmelerinde ne yolda hareket etmiş olduklarını bildirmek zorunda kaldı. (TBMM Zabıt Ceridesi, Cilt. 7, 3/1/1921, s. 148) İngiliz istihbaratına göre söz konusu nota 7 Aralık'ta yazılmıştı ve notada Türk Milliyetçilerinin kabul etmiş oldukları üstlenmeleri (herhalde telgrafta önerilen koşulları) yerine getirmek azminde olduklarını da bildirmişti. (Sonyel, 2013, ss. 135-136) Aynı gün Yeşil Ordu Cemiyeti'nden ayrılan komünistlerin kurduğu Türkiye Halk İştirakiyun Fırkası'na faaliyet ruhsatı verildi. (Jaeschke, 1989, s. 132)

1- Fakat Bakü'de kurulmuş olan Türkiye Komünist Fırkası'nın Reisi Mustafa Suphi ve arkadaşları, Ocak 1921'de Türkiye'ye geldi. Onları ciddi bir tehlike olarak gören Mustafa Kemal, Ahmet Muhtar'ın Çiçerin'e yazdığı notayı unutmuş göründü. Mustafa Suphi ve arkadaşları aleyhinde protesto gösterileri düzenleterek, onları sınır dışı ettirdi. (Topal, 2018, s. 320) Öte yandan Ocak-Ağustos 1921 boyunca Türk orduları, Yunanlılar karşısında sürekli geri çekiliyordu. Durumu endişeyle izleyen Bolşevik Hükümeti, Mart 1921'de BMM Hükümeti ile Dostluk ve Kardeşlik Antlaşması yapmış ve kesintili olarak askeri yardıma devam etmiş olsa da 1921 yazına kadar Enver Paşa'yı, Bolşevik ordularının başında Batum'dan Anadolu'ya girmesi için hazırlamıştı bile. Ancak Türk ordusu, Ağustos- Eylül 1921'deki ölüm-kalım muharebesinde Yunanlıları büyük fedakarlıklarla Sakarya'da durdurdu. 22 Haziran 1922 tarihli İngiliz istihbaratına göre, Bolşeviklerin ciddiyetini anlayan Mustafa Kemal büyük bir endişeyle, Sakarya Muharebesinden hemen sonra Moskova'ya kurye (Sami Bey) ile kişisel ve gizli bir taahhütname gönderdi. Bolşeviklerden, kendisinin komünist ilkelere olan bağlılı̆ını açıkça beyan etmeye zorlamamalarını istedi. Onlar da bu

\footnotetext{
${ }^{8}$ Bilecik Görüşmeleri ile ilgili ayrıntılı bilgi için bkz. Taner Bilgin, Anadolu Yükselirken 100. Yılında Bilecik Mülakatı 5 Aralık 1920-2020, Babıali Yay., İstanbul, 2020
}

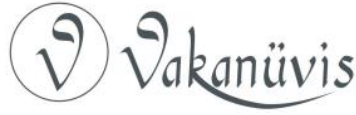


teminattan memnun kaldı. (Salâhi R. Sonyel, "Mustafa Kemal and Enver in Conflict, 1919-1922", Middle Eastern Studies, Vol. 25, No. 4 (1989), pp. 512-513) 30 Eylül'de BMM'nin çıkardığı afla, Mayıs ayında mahkûm edilen eski Yeşil Ordu Cemiyeti (Türkiye Halk Iş̧tirakiyun Fırkası) komünistleri serbest bırakıldı. (Jaeschke, 2011, s. 171) Öyle anlaşılıyor ki Bolşeviklerin telgrafı yaklaşık bir yıl sonra esas etkisini göstermiş ve Mustafa Kemal Türkiye'nin komünist ilkelere uyacağını teyit etmişti.

2- Aynı İngiliz istihbarat raporuna göre Mustafa Kemal söz konusu mektubunda, Anadolu yönetiminde gereken tüm değişikliklerin aşamalı olarak yapılması gerektiği hususunu da belirtmişti. (Sonyel, 1989, p. 513) Aslında ılımlı bir milliyetçi denilebilen (Sonyel, 2013, ss. 114-115) hatta Hilafete-Saltanata bağlı bir muhafazakâr ${ }^{9}$ olan Mustafa Kemal, bu andan itibaren mecburen bir devrimci milliyetçi oldu ve Kasım 1922'de saltanatı kaldırttı. Ekim 1923'de de üç yıl önce Pozantı Kongre bildirisini (doğruysa) imzaladığı sıfatı (Türkiye Cumhurbaşkanı) kazandı.

3- Saltanatın kaldırılmasıyla Halifelik BMM'nin uhdesine verilmişti. ilginçtir Bolşevikler Halifeliğin kaldırılmasını istememişti. Yeşil Ordu Cemiyeti veya başka bir komünist parti iktidarı elde etseydi, padişahlık iptal edildiğinde partinin Müslüman genel sekreteri Halife olacaktı.

\footnotetext{
${ }^{9}$ Halife Padişahın Fahri Yaveri olan Mustafa Kemal, İngilizlerin İstanbul Hükümeti'ne baskısı neticesinde askerlikten istifa ederken Halifeye de şu telgrafı göndermişti: “9/7/1919, Erzurum, ... Atabei Ulyayi (Pek Yüce Atabeyi) Hazreti Padişahiye: Makamı Uzmayi Saltanat (Büyük Saltanat Makamına) ve Hilâfetin (Hilafete) ve milleti necibelerinin (soylu milletine) hayatımın son noktasına kadar daima haris ve sadık bir ferdi gibi kalacağımı kemali ubudiyetle (eksiksiz kullukla) arz ve temin eylerim. Kulları Mustafa Kemal." (TBMM Zabıt Ceridesi, Cilt 1, 24/4/1920, ss. 15-16) Öte yandan iç ayaklanmalar, İstanbul'un işgali ve Bolşevik Rusya ile anlaşmadan sonra Mustafa Kemal, Aralık 1920'de BMM'de “... Hilâfet ve saltanat mahfuziyeti (korunması) zaten birinci esasımızdır. Hakikaten düşündüğümüz halâsı hakikiye vusul (gerçek kurtuluşa varmak) için, arz ettiğim veçhile makamı hilâfet ve saltanat olan merbutiyetimiz (bağıı̆̆ımız) ve o makamın bütün şeraiti (şartları) lâzimesiyle mahfuziyeti birinci esasımızdır." diye beyan etmiş; fakat devamında "... Bugün bu makamı işgal eden zat bu millet ve memleket için hain bir adamdır. (Alkışlar) ... Hain bir adamdır. (Alkışlar, bravo sadaları) ... Maateessüf (Üzülerek) şimdi makamı hilâfet ve saltanatı işgal eden zat bu millet için hain bir adamdır..." (TBMM Gizli Celse Zabıtları, Cilt. 1, 25/9/1920, s. 135) derken de devrimin ayak sesleri BMM'de üç defa yankılanmıştır.
}

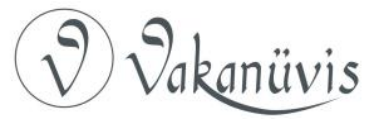


4- Yine Mart 1924'te Şer'iye ve Evkaf Vekilliklerinin kapatılması ve Tevhid-i Tedrisat Kanunun çıkarılması, Nisan 1924'te Şer'iye Mahkemelerinin kaldırıması, Kasım 1925'te Tekke ve Zaviyeler ile Türbelerin kapatılması ve Nisan 1928 'de Anayasa'daki devletin dininin İslam olduğu cümlesinin kaldırılması gibi laiklik yolunda yapılan birçok devrimden sonra Şubat 1937'de, laiklik ilkesi anayasaya girdi.

5- Kadınların peçesi yasaklanmadığı halde, peçenin atılması için propaganda yapıldı. Kadınların özgürleşmesi için Şubat 1926'da Medeni Kanunun kabulü, Nisan 1930 ve Aralık 1934'de seçme ve seçilme haklarının verilmesi gibi birçok devrim yapıldı.

6- Erivan (Ermeni) Cumhuriyetine karşı harekât, Kazım Karabekir komutasında Eylül ayında başlamış, Kasım ayında sona ermişti. Bolşevik Rusya Hükümeti harekatın başlamasından sonra bir ay boyunca ses çıkarmamıştı. Fakat Türk ordusu Kars'a taarruz ederken, Çiçerin telgrafla harekatın durdurulmasını talep etti. Ancak Kars'ın Elviye-yi Selase içinde olması nedeniyle BMM Hükümeti, 30 Ekim'de burayı da işgal ettikten sonra 1 Kasım'da Ermenistan'a sulh teklif etti. Ermeni Hükümeti bu teklife 3 Kasım'da tereddütlü cevap verince, Türk harekâtı Gümrü'ye doğru yeniden başladı ve 18 Kasım'da kalıcı ateşkes yapılana kadar devam etti. (Jaeschke, 1989, ss. 126-127, 129)

7- Türkiye, Sovyet Hükümeti'nin yaptığı ve yapacağı tüm antlaşmaları tanıyacaktı. illk bakışta bağımsızlığı sınırlayıcı bir şart gibi görünmesine rağmen, daha sonra Moskova Antlaşmasının 1. Maddesindeki, Bolşevik Rus Hükümeti “Büyük Millet Meclisi Hükümeti tarafından tanınmamış Türkiye'ye ilişkin hiçbir uluslararası anlaşmayı tanımamayı kabul eder" hükmüyle, taraflar kendi aralarında dış politikada birlik sağlamıştı. (İsmail Soysal, Türkiye'nin Siyasal Antlaşmaları, I. Cilt (1920-1945), T.T.K Basımevi, Ankara, 1983, ss. 3238) Zaten tarafların, birbirinin yaptığı/tanıdığı antlaşmaları tanımaması gibi bir durum hiç meydana gelmedi. Bu, Binbaşı Bray'in Anadolu Hükümeti'nin, İslamiyet'in amaçları elde edilir edilmez Bolşeviklerle ilişkiyi keseceği öngörüsünde yanıldığını, BMM Hükümeti bir yandan Lozan'da kapitalist Batı dünyasıyla barış yaparken bir yandan da Bolşeviklerle siyasi ittifakı devam ettirdiğini göstermektedir.

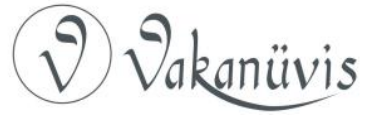


8- Türk heyetleri Ağustos 1920 ve Şubat 1921'de Moskova'dayken Bolşevik Hükümeti'yle askeri ittifak yapmak istemiş, fakat Hükümet temsilcileri iki defa reddetmişti. İlkinde Dışişleri Halk Komiserliğinden bir yetkili Türkiye'nin komünist ülke olmadığı, ikincisinde Çiçerin ve Stalin Ingilizlerle ticaret anlaşması yapmak üzere oldukları gerekçesiyle böyle bir ittifak yapamayacaklarını söylemişti. (Sonyel, 2003, ss. 14, 52-53) Türkiye komünist ilkeleri benimsediğini ilan etmediğinden, Türk "Sovyet" Hükümeti olmamıştı. Bu nedenle Bolşeviklerle bir askeri ittifak ve sözleşme yapıl(a)madı.

\section{Sonuç}

Bu makalede Birleşik Krallık Hindistan Ofisi siyasi istihbarat subayı Binbaşı Norman N. E. Bray'in, 18 Kasım 1920 tarihli “Ortadoğu'da Durum" isimli çok gizli kurum notu ekindeki iki belge incelenmiş ve analiz edilmiştir. illk belgenin analizi sonucunda, BMM ile Bolşevik Rusya arasında Moskova Antlaşması imzalanmadan sekiz ay önce taraflar arasında bir askeri-siyasi anlaşma (mutabakat) yapıldığı; anlaşma ile BMM Hükümeti'nin dış siyaset esaslarının belirlendiği; KemalistBolşevik (ve Alman) Kutsal İttifak'ının ilan edildiği ve anlaşmanın, Moskova Antlaşmasının gizli eki/maddeleri haline getirildiği görülmüştür. Diğer belgenin analizinde ise Mustafa Kemal'in Milli Mücadele başlangıcında ılımlı bir Türk milliyetçisi ve muhafazakarı nitelenebilecek olmasına rağmen, Bolşeviklerin baskısıyla devrimci milliyetçiye dönüştüğü; Bolşeviklerin, Türk Milliyetçilerin kabul etmesi için gönderdiği söz konusu telgraftaki şartlar hem Hükümet hem de kişisel olarak Mustafa Kemal Atatürk tarafından yazılı olarak kabul edildiği için Mudanya Ateşkesinden sonra yapılan devrimlerin, bu kabulün gereği pacta sunt servanda olduğu anlaşılmıştır.

\section{Kaynakça}

Aydemir, Ş. Süreyya, Tek Adam, Cilt. 2, Remzi Kitabevi, Simge Yayınclık, 1999

Bilgin, Taner, Anadolu Yükselirken 100. Yılında Bilecik Mülakatı 5 Aralık 1920-2020, Babıali Yay., İstanbul, 2020

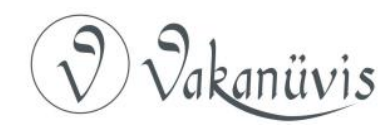


Çanak, Erdem, "Atatürk'ün Adana Ziyaretleri", Atatürk Araştırma Merkezi Dergisi, C. 30, S. 90 (2014): ss. 49-82

Erdaş, Sadık, "Türk-Sovyet ilişkilerinin IIlk Yılı ve Iki Kararname", Cumhuriyet Tarihi Araştırmaları Dergisi, Yıl. 13, Sayı. 26 (2017), ss. 67-90

Jaeschke, Gotthard, Çev. Zamantılı, Hüseyin, "1919-1939 Yılları Arasındaki Türk-Rus Yakınlaşması Hakkında Bir Inceleme" (Atatürk Dönemi Sovyet Politikası Hakkında), Istanbul Journal of Sociological Studies, C. 0, S. 19 (2011), ss. $159-174$

Jaeschke, Gotthard, Türk Kurtuluş Savaşı Kronolojisi, Mondros'tan Mudanya'ya Kadar, TTK Basımevi, Ankara, 1989

Karabekir, Kâzım, İstiklâl Harbimiz, Cilt. 1- 2, Yapı Kredi Yayınları, İstanbul, 2008

Major Bray, E. E. Norman, Mesopotamia. Causes of Unrest, Report No. II, 1920a, India Office

Major Bray, E. E. Norman, Situation in Middle East, 1920b, India Office

Sonyel, R. Salâhi, "Mustafa Kemal and Enver in Conflict, 1919-1922", Middle Eastern Studies, Vol. 25, No. 4 (1989), pp. 506-515

Sonyel, R. Salâhi, Kurtuluş Savaşı Günlerinde ingiliz Istihbarat Servisi'nin Türkiye'deki Eylemleri, 2. Baskı, TTK Basımevi, Ankara, 2013

Sonyel, R. Salâhi, Türk Kurtuluş Savaşı ve Dış Politika II, 3. Baskı, TTK Basımevi, Ankara, 2003

Soysal, İsmail, Türkiye'nin Siyasal Antlaşmaları, I. Cilt (1920-1945), T.T.K. Basımevi, Ankara, 1983

TBMM Gizli Celse Zabıtları, Cilt. 1, 3/7/1920, gcz01001026.pdf (tbmm.gov.tr) adresinden 10/12/2020 tarihinde erişildi.

TBBM Gizli Celse Zabıtları, Cilt. 1, 25/9/1920, gcz01001072.pdf (tbmm.gov.tr) adresinden 13/12/2020 tarihinde erişildi.

TBMM Zabit Ceridesi, Cilt. 1, 24/4/1920, tbmm01001002.pdf adresinden 13/12/2020 tarihinde erişildi.

TBMM Zabıt Ceridesi, Cilt. 2, 8/7/1920, tbmm01002030.pdf adresinden 10/12/2020 tarihinde erişildi.

TBMM Zabıt Ceridesi, Cilt. 7, 3/1/1921, tbmm01007128.pdf adresinden 13/12/2020 tarihinde erişildi.

Tekeli, Illhan ve IIlkin, Selim, "Kurtuluş Savaşında Talat Paşa ile Mustafa Kemal'in Mektuplaşmaları", Belleten, TTK Basımevi, C. 44, S. 174 (1980), ss. 301-346

Topal, Coşkun, "Türk-Rus iliş̧kileri ve Moskova Anlaşması", Karadeniz Araştırmaları Enstitüsü Dergisi, 4/6 (2018), ss.313-330

Yalçın, E. Semih, "Dahiliye Vekili Nazım Bey'in İstifası Meselesi", Atatürk Araştırma Merkezi Dergisi, C. XI, S. 32 (1995), ss. 405-416.

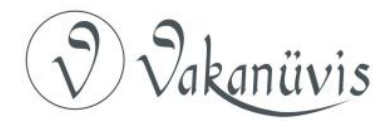

